\title{
Removing Heavy Metals through Different Types of Soils and Marble Powder found in Oman
}

\author{
Aref Wazwaz ${ }^{*}$, Ahmed Al-Salaymeh², Mohd Shariq Khan' \\ 1 Chemical Engineering Department, Dhofar University, P.O. Box 2509, Salalah, Oman \\ 2 Mechanical Engineering Department, The University of Jordan, P.O. Box 13533, Amman, Jordan \\ * Corresponding author's e-mail: aref@du.edu.om
}

\begin{abstract}
In this research, adsorption followed by filtration was used for removing heavy metals $(\mathrm{Cu}, \mathrm{Zn}, \mathrm{Mn}$, and $\mathrm{Cr}$ ) from the polluted water. Three types of soils (silty, sandy and clay) and three types of marble powder (pure, impure, marble-granite mix) were used as an adsorbent. The soil and marble samples were collected from different regions of Oman. The maximum adsorption obtained was $96.01 \%$ for $\mathrm{Zn}$ using pure marble powder and the minimum adsorption obtained was $6.70 \%$ for Mn using impure marble powder. Through different soils, the maximum adsorption of $88.61 \%$ was achieved for $\mathrm{Zn}$ using clay and the lowest one is for $\mathrm{Cr} 16.51 \%$ using silty soil. The results suggest that among the marble powders, the pure ones show the maximum $(96.01 \%$ for $\mathrm{Zn}$ ) and marble-granite show the minimum (Mn 6.70\%) adsorption performance. Among the adsorbents, $\mathrm{Zn}$ is the best adsorbate (96.01\%) while the worst among the group is $\mathrm{Mn}$, which merely adsorbed $6.70 \%$ with the selected adsorbents.
\end{abstract}

Keywords: adsorption; potable water; silty soil; sandy soil; clay soil; marble powder; heavy metals removal

\section{INTRODUCTION}

Clean water is the most important material on Earth due to its functional and metabolic role for the survival of plant and animal life. Growing populations and human activities related to industrial applications produce a lot of heavy metals that reach water bodies on the surface and under the soil. The concentrations of these heavy metals exceeding certain limit are dangerous to human life. There is a great concern with water safety and availability as a result of heavy metals polluting water ( $\mathrm{Yu}$ et al., 2000).

Heavy metals are highly toxic and nonbiodegradable materials; this leads to their bio-accumulation, causing health problems and bad effects on the environment (Inyang et al., 2012). Heavy metals are elements with the density exceeding $5.0 \mathrm{~g} / \mathrm{mL}$, most of them are soluble in water. The following heavy metals are commonly found; Copper $(\mathrm{Cu}), \mathrm{Zinc}(\mathrm{Zn})$, Gold $(\mathrm{Au})$, Mercury ( $\mathrm{Hg})$, Cadmium $(\mathrm{Cd})$, Iron
(Fe), Nickel (Ni), Tin (Sn), Arsenic (As), Selenium (Se), Molybdenum (Mo), Cobalt (Co), Manganese (Mn) and Aluminium (Al) (Gunatilake. 2015).

There are different techniques used for removing heavy metals from water. These include; i) Chemical precipitation, ii) Ion-Exchange, iii) Chemical Oxidation and Reduction, iv) Filtration, v) Membrane Technology, vi) Reverse Osmosis, vii) Neutralization, viii) Electrochemical Treatment, ix) Electrodialysis, x) Flotation, xi) Electroflotation, xii) Electrolytic recovery and Evaporation (Akbal \& Camci. 2011).

Most of these mentioned techniques are too expensive or ineffective; the simple physicosorption technique is most useful and costeffective for heavy metal removal (Kobya et al., 2005). Many types of research adopted one of these mentioned techniques for heavy metal adsorption utilizing low-cost materials like protein granules, peat, redmud, potato peels, sawdust, phosphate rock, tourmaline, and 
activated carbon (Nodoushan \& Ehrampoush. 2015) (Carmalau, 2009) (Aman et al., 2008) (Sarioglu et al., 2005) (Jiang et al., 2006). Gruszecka (Gruszecka et al., 2017) studied the powder of dolomite as adsorbents for removing heavy metals. Migahed (Migahed et al., 2017) used bio adsorbent (microbial consortia) to remove heavy metals. Inspired by those studies, this research also attempted to find a cheap adsorption material for the removal of heavy metals. There are different types of soils spread all over Oman, including clayey, silty, loamy, sandy, peaty, and chalky soils. These soils have the ability to adsorb heavy metals. Marbles find different applications in Oman including building construction, in kitchen and decoration. There are many factories all through Oman that produce and cut marbles for the aforementioned applications. During the cutting of marbles, a lot of marble powder is produced and disposed of in the environment. That gives us the opportunity to look for the absorption properties in this discarded marble powder. In this study, we took these samples of marble powder and different types of soils found in Oman and tested them for the removal of heavy metals.

\section{EXPERIMENTAL}

The samples were collected from different regions in Oman. There are six types of samples used in this study which are illustrated in Figure 1:

- Type I (Soil): a. Silty soil; b. Sandy soil; c. Clayey soil.

- Type II (Marble Powder): d. Pure marble; e. Impure marble; f. Marble-granite mix.

The samples were washed with distilled water several times and then dried by putting them in the oven at $300^{\circ} \mathrm{C}$ for 1 hour.

The surface of the adsorbent samples was checked using a Scanning Electron Microscope. Scanning Electron Microscopy (SEM) was performed for all the surfaces of the adsorbents samples using emission scanning electron microscopes (SEMs) (MIRA FE-SEMs). The chamber used was XM.

The samples ( $10 \mathrm{~g}$ of adsorbents) were put in $200 \mathrm{~mL}$ of water containing a known concentration of heavy metal at ambient temperature for 1 hour. Then, the mixtures were filtered using Buchner funnel to obtain a clear filtrate. Finally, the concentration of heavy metal in the filtrate was checked by atomic absorption spectrometer. The whole experimental procedure is illustrated in Figure 2.

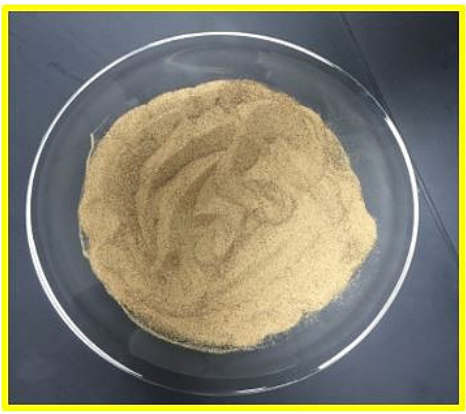

(a) Silty soil

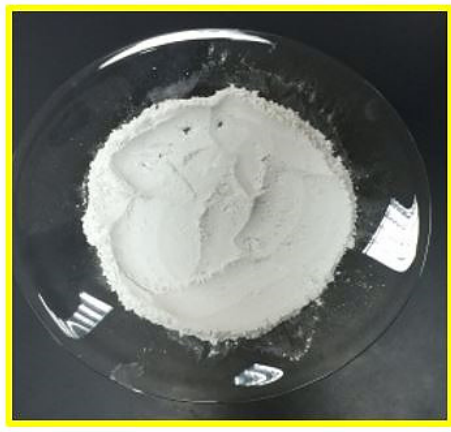

(d) Pure marble powder

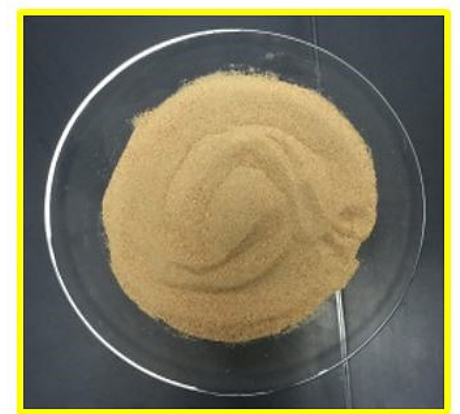

(b) Sandy soil

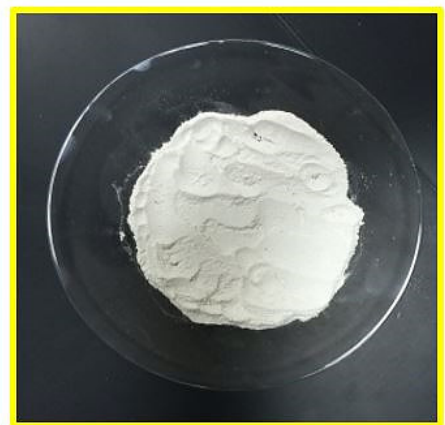

(e) Impure marble powder

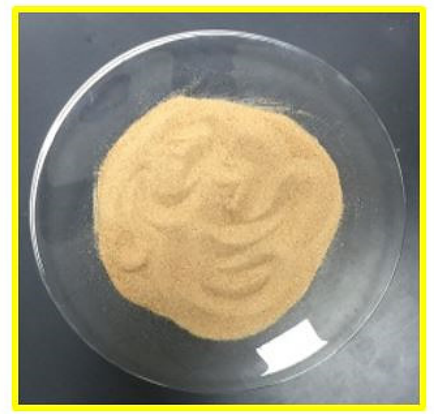

(c) Clay soil

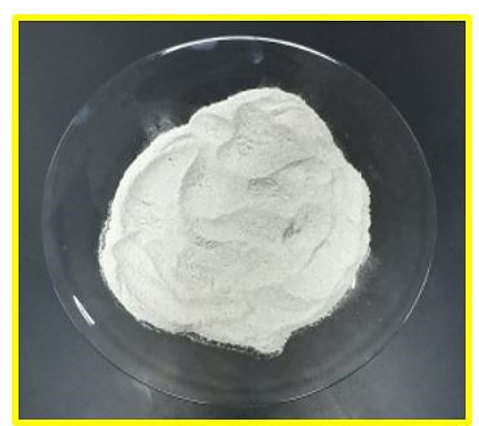

(f) Mix marble- granite powder

Figure 1. Sand and marble powder samples used as an adsorbent 


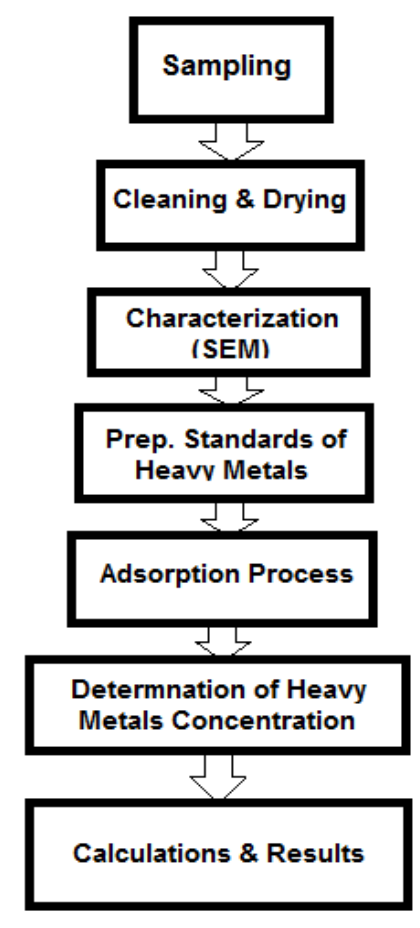

Figure 2. Experimental set-up for the removing of the heavy metals

\section{RESULTS AND DISCUSSION}

The distilled water used to prepare the heavy metal standards was taken from the locally installed water distillator. Its specifications are shown in Table 1.

The Electron Microscopy was done for all samples. The SEM images for the samples are shown in Figures 3 to 7. The SEM images revealed that the surfaces of the soils were approximately comparable in morphology and the same is also true for the surfaces of the marble powders. SEM images further revealed that the surfaces of marble powders were of lower granule size than the ones of soil samples. Thus, we expect a higher adsorption rate in the case of marble powder in relation to soils.

The concentrations of the heavy metals before (standard concentration) and after adsorption are shown in Tables 2 to 11 . The concentrations before and after adsorption in silty soil samples are shown in Table 2. Figure 8 illustrates the result of Table 2. Figure 9 illustrates the results of Table 3. Figure 10 illustrates the results of Table 4. Figure 11 illustrates the results of Table 5. Figure 12 illustrates the results of Table 6. Figure 13 illustrates the results in Table 7.

The calculations of the adsorption percentage for all samples (adsorbents) with all heavy metals (adsorbate) are summarized in Table 8.
Table 1. The specifications of distilled water used in the preparations of heavy metal standards

\begin{tabular}{|c|c|}
\hline Specifications & Value \\
\hline $\mathrm{pH}( \pm 0.01)$ & 7.99 \\
\hline $\mathrm{EC}(\mu \mathrm{S} / \mathrm{cm})( \pm 1)^{1}$ & 52200 \\
\hline $\operatorname{TDS}(\mathrm{mg} / \mathrm{L})( \pm 0.1)^{2}$ & 36540.0 \\
\hline T. Hardness $\left(\mathrm{mgCaCO}_{3} / \mathrm{L}\right)( \pm 0.01)^{3}$ & 6142.00 \\
\hline C. Hardness $\left(\mathrm{mg} \mathrm{CaCO}_{3} / \mathrm{L}\right)( \pm 0.01)^{4}$ & 1018.50 \\
\hline M. Hardness $\left(\mathrm{mgCaCO}_{3} / \mathrm{L}\right)( \pm 0.01)^{5}$ & 5123.50 \\
\hline T. Alkalinity $\left(\mathrm{mgCaCO}_{3} / \mathrm{L}\right)( \pm 0.01)^{6}$ & 263.30 \\
\hline $\mathrm{HCO}_{3}-$ Alkalinity $\left(\mathrm{mgCaCO}_{3} / \mathrm{L}\right)( \pm 0.01)$ & 263.30 \\
\hline Turbidity (NTU) ( \pm 0.01$)$ & 0.20 \\
\hline L. Index $( \pm 0.01)^{7}$ & 1.31 \\
\hline $\mathrm{Ca}^{+2}(\mathrm{mg} / \mathrm{L})( \pm 0.01)$ & 407.40 \\
\hline $\mathrm{Mg}^{+2}(\mathrm{mg} / \mathrm{L})( \pm 0.01)$ & 1228.66 \\
\hline $\mathrm{Na}^{+} \quad(\mathrm{mg} / \mathrm{L})( \pm 0.1)$ & 7800.0 \\
\hline $\mathrm{K}^{+}(\mathrm{mg} / \mathrm{L})( \pm 0.01)$ & 437.5 \\
\hline Silica $(\mathrm{mg} / \mathrm{L})( \pm 0.01)$ & 0.00 \\
\hline $\mathrm{Cl}(\mathrm{mg} / \mathrm{L})( \pm 0.01)$ & 14704.92 \\
\hline $\mathrm{SO}_{3}^{-2}(\mathrm{mg} / \mathrm{L})( \pm 0.1)$ & 2618.8 \\
\hline $\mathrm{NO}_{3}(\mathrm{mg} / \mathrm{L})( \pm 0.01)$ & 0.00 \\
\hline $\mathrm{F}^{-}(\mathrm{mg} / \mathrm{L})( \pm 0.001)$ & 2.79 \\
\hline $\mathrm{PO}_{4}^{-3}(\mathrm{mg} / \mathrm{L})( \pm 0.001)$ & 0.001 \\
\hline
\end{tabular}

${ }^{1}$ Electrical conductivity, ${ }^{2}$ Total dissolved solids, ${ }^{3}$ Total hardness, ${ }^{4}$ Carbonate hardness, ${ }^{5}$ Magnesium hardness, ${ }^{6}$ Total alkalinity, ${ }^{7}$ Langellie index.

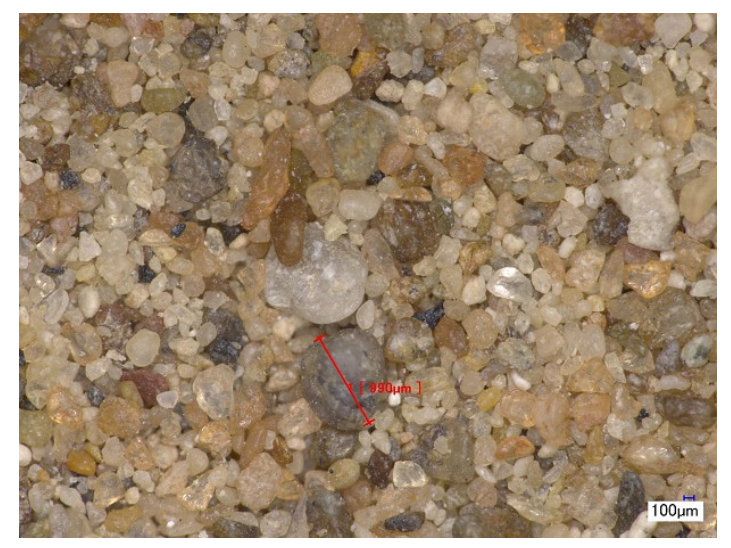

Figure 3. SEM image for a silty soil sample

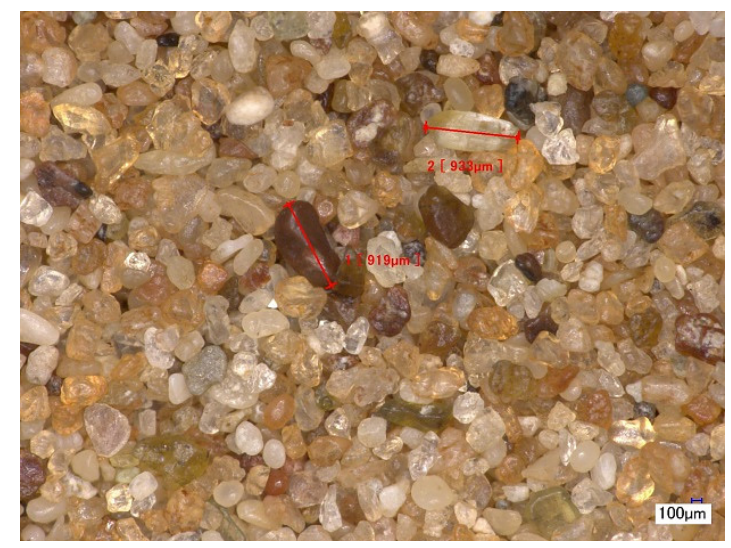

Figure 4. SEM image for a clayey soil sample 


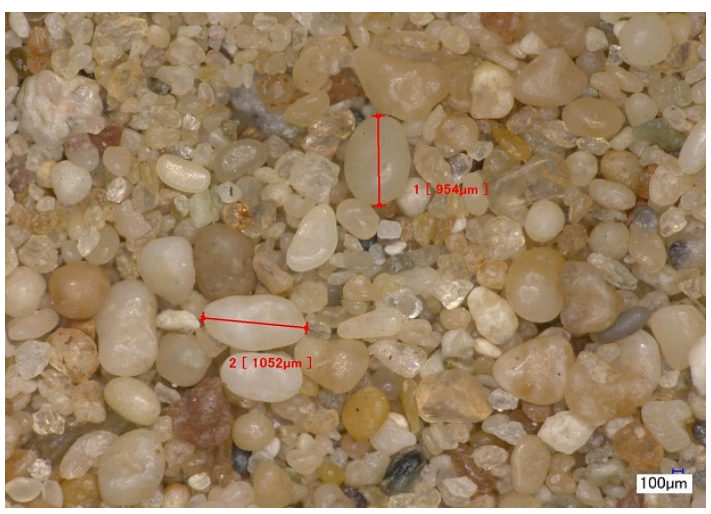

Figure 5. SEM image for a sandy soil sample

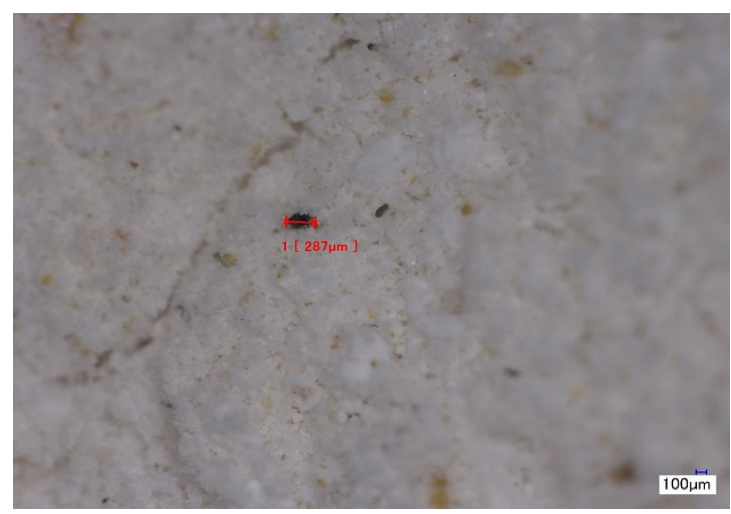

Figure 6. SEM image for impure marble sample

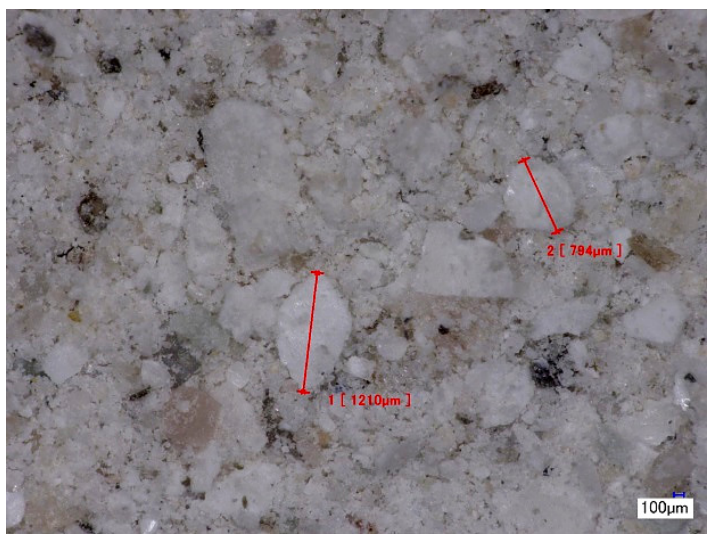

Figure 7. SEM for marble-granite mix sample
Table 2. Concentrations of heavy metals in silty soil samples

\begin{tabular}{|c|c|c|c|c|}
\hline \multirow{2}{*}{$\begin{array}{c}\text { Sample } \\
\text { description }\end{array}$} & \multicolumn{4}{|c|}{ Concentration $( \pm 0.0001 \mathrm{ppm})$} \\
\cline { 2 - 5 } & $\mathrm{Cu}$ & $\mathrm{Zn}$ & $\mathrm{Mn}$ & $\mathrm{Cr}$ \\
\hline $\begin{array}{c}\text { Before } \\
\text { adsorption }\end{array}$ & 0.0337 & 0.2705 & 0.0194 & 0.0218 \\
\hline $\begin{array}{c}\text { After } \\
\text { adsorption }\end{array}$ & 0.0083 & 0.0334 & 0.0037 & 0.0182 \\
\hline
\end{tabular}

Table 3. Concentrations of heavy metals in sandy soil samples

\begin{tabular}{|c|c|c|c|c|}
\hline \multirow{2}{*}{$\begin{array}{c}\text { Sample } \\
\text { description }\end{array}$} & \multicolumn{4}{|c|}{ Concentration $( \pm 0.0001 \mathrm{ppm})$} \\
\cline { 2 - 5 } & $\mathrm{Cu}$ & $\mathrm{Zn}$ & $\mathrm{Mn}$ & $\mathrm{Cr}$ \\
\hline $\begin{array}{c}\text { Before } \\
\text { adsorption }\end{array}$ & 0.0337 & 0.2705 & 0.0194 & 0.0218 \\
\hline $\begin{array}{c}\text { After } \\
\text { adsorption }\end{array}$ & 0.0080 & 0.0312 & 0.00341 & 0.0163 \\
\hline
\end{tabular}

Table 4. Concentrations of heavy metals in clay soil samples

\begin{tabular}{|c|c|c|c|c|}
\hline \multirow{2}{*}{$\begin{array}{c}\text { Sample } \\
\text { description }\end{array}$} & \multicolumn{4}{|c|}{ Concentration $( \pm 0.0001 \mathrm{ppm})$} \\
\cline { 2 - 5 } & $\mathrm{Cu}$ & $\mathrm{Zn}$ & $\mathrm{Mn}$ & $\mathrm{Cr}$ \\
\hline $\begin{array}{c}\text { Before } \\
\text { adsorption }\end{array}$ & 0.0337 & 0.2705 & 0.0194 & 0.0218 \\
\hline $\begin{array}{c}\text { After } \\
\text { adsorption }\end{array}$ & 0.0078 & 0.0308 & 0.0033 & 0.0150 \\
\hline
\end{tabular}

Table 5. Concentrations of heavy metals in pure marble samples

\begin{tabular}{|c|c|c|c|c|}
\hline \multirow{2}{*}{$\begin{array}{c}\text { Sample } \\
\text { description }\end{array}$} & \multicolumn{4}{|c|}{ Concentration $( \pm 0.0001 \mathrm{ppm})$} \\
\cline { 2 - 5 } & $\mathrm{Cu}$ & $\mathrm{Zn}$ & $\mathrm{Mn}$ & $\mathrm{Cr}$ \\
\hline $\begin{array}{c}\text { Before } \\
\text { adsorption }\end{array}$ & 0.0337 & 0.2705 & 0.0194 & 0.0218 \\
\hline $\begin{array}{c}\text { After } \\
\text { adsorption }\end{array}$ & 0.0026 & 0.0108 & 0.0095 & 0.0093 \\
\hline
\end{tabular}

Table 6. Concentrations of heavy metals in impure marble samples

\begin{tabular}{|c|c|c|c|c|}
\hline \multirow{2}{*}{$\begin{array}{c}\text { Sample } \\
\text { description }\end{array}$} & \multicolumn{4}{|c|}{ Concentration $( \pm 0.0001 \mathrm{ppm})$} \\
\cline { 2 - 5 } & $\mathrm{Cu}$ & $\mathrm{Zn}$ & $\mathrm{Mn}$ & $\mathrm{Cr}$ \\
\hline $\begin{array}{c}\text { Before } \\
\text { adsorption }\end{array}$ & 0.0337 & 0.2705 & 0.0194 & 0.0218 \\
\hline After adsorption & 0.0029 & 0.0112 & 0.0181 & 0.0123 \\
\hline
\end{tabular}

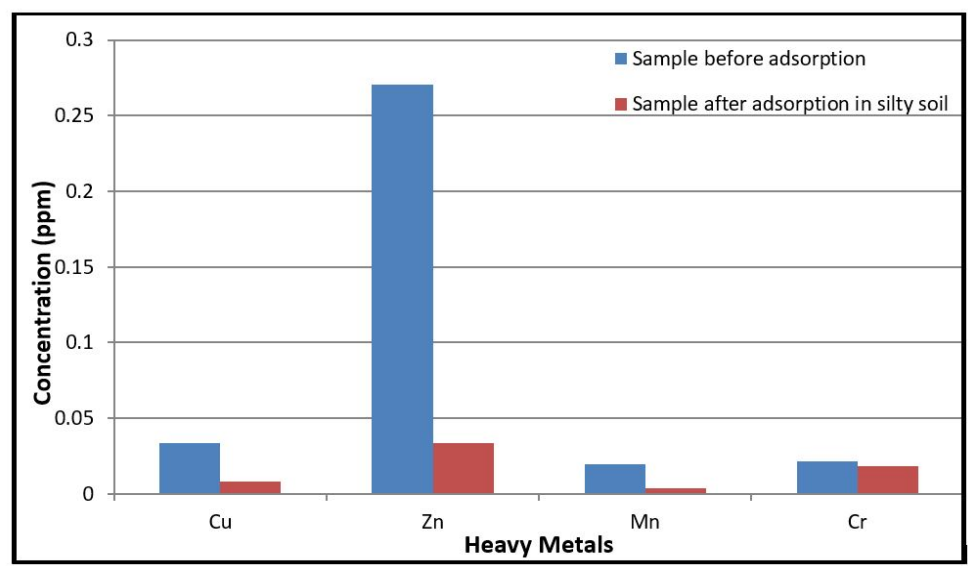

Figure 8. The concentrations of heavy metals before and after adsorption in silty soil samples 


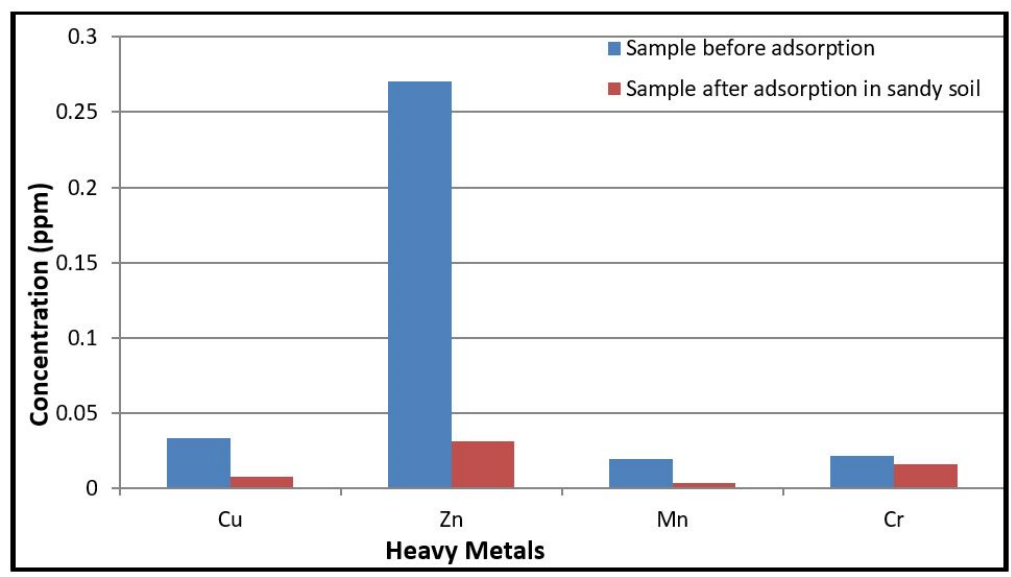

Figure 9. The concentrations of heavy metals before and after adsorption in sandy soil samples

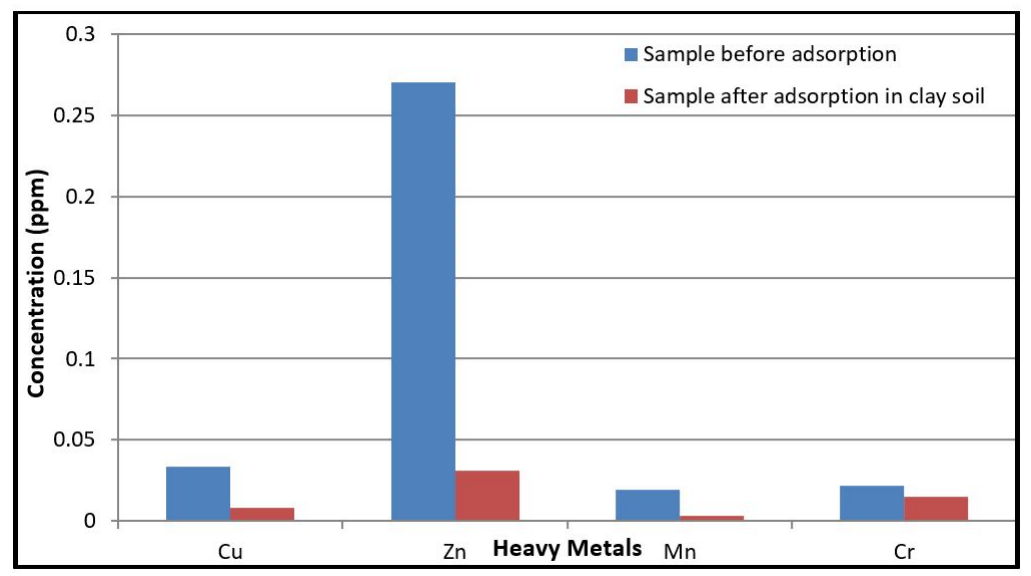

Figure 10. The concentrations of heavy metals before and after adsorption in clayey soil samples.

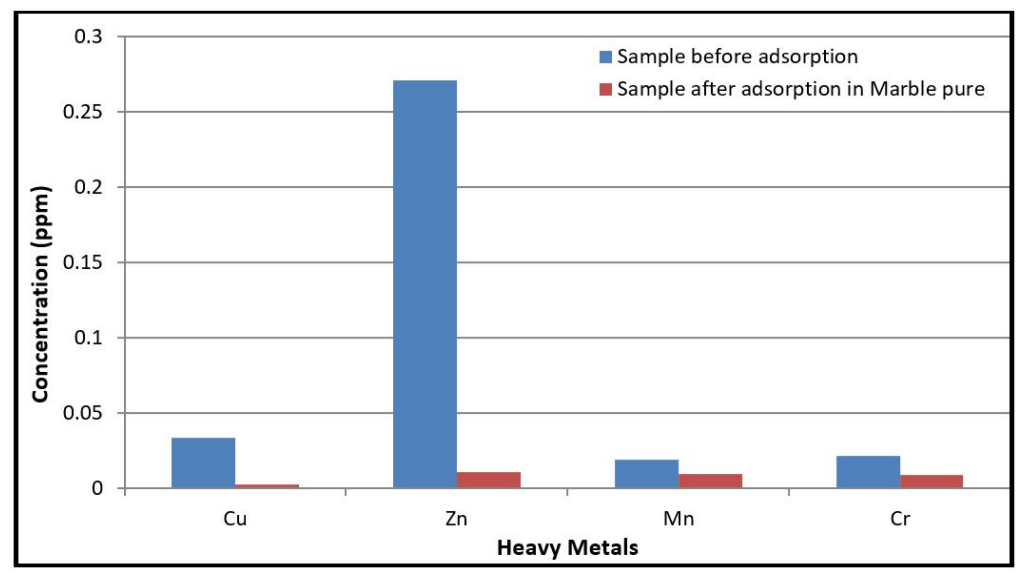

Figure 11. The concentrations of heavy metals before and after adsorption in pure marble samples

Table 7. Concentrations of heavy metals in marble-granite mix samples

\begin{tabular}{|c|c|c|c|c|}
\hline \multirow{2}{*}{ Sample description } & \multicolumn{4}{|c|}{ Concentration $( \pm 0.0001 \mathrm{ppm})$} \\
\cline { 2 - 5 } & $\mathrm{Cu}$ & $\mathrm{Zn}$ & $\mathrm{Mn}$ & $\mathrm{Cr}$ \\
\hline Before adsorption & 0.0337 & 0.2705 & 0.0194 & 0.0218 \\
\hline After adsorption & 0.0029 & 0.0118 & 0.0141 & 0.0138 \\
\hline
\end{tabular}




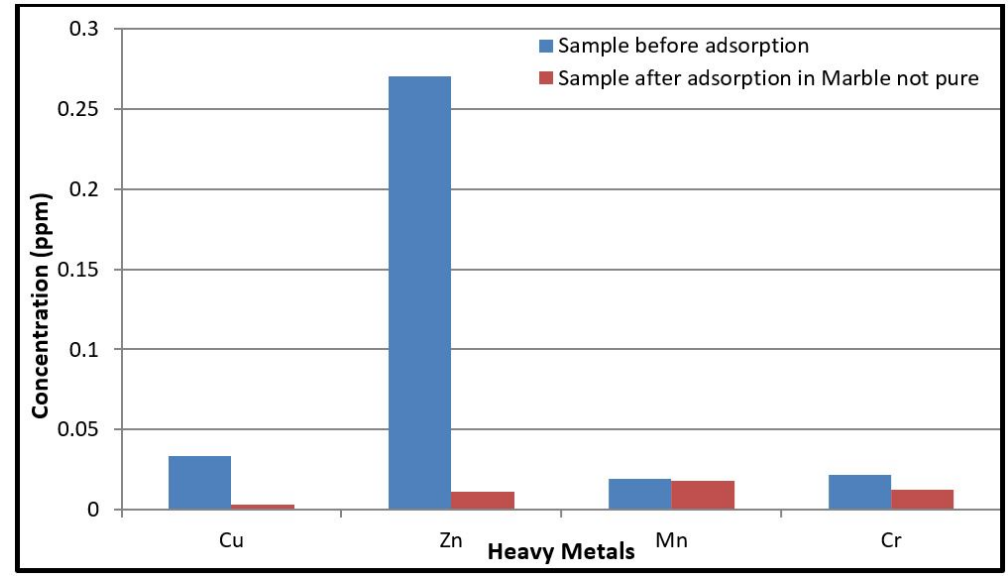

Figure 12. The concentrations of heavy metals before and after adsorption in impure marble samples

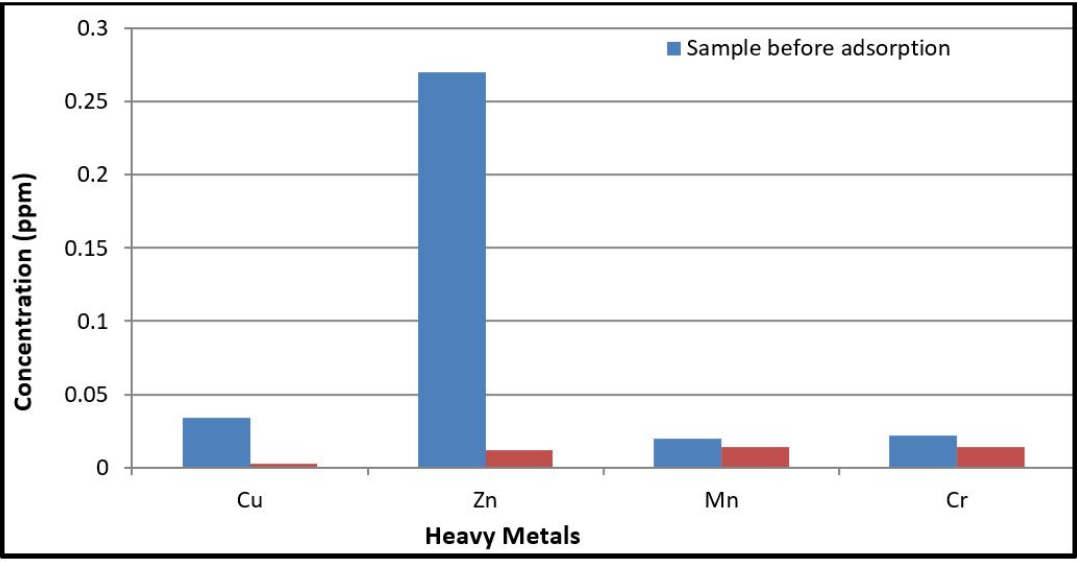

Figure 13. The concentrations of heavy metals before and after adsorption in marble-granite mix samples

Table 8. Summary of adsorption percentage for all samples used in the adsorption process

\begin{tabular}{|l|c|c|c|c|}
\hline \multirow{2}{*}{ Sample type } & \multicolumn{4}{c|}{ Adsorption $(\% \pm 0.01)$} \\
\cline { 2 - 5 } & $\mathrm{Cu}$ & $\mathrm{Zn}$ & $\mathrm{Mn}$ \\
\hline Silty soil & 75.37 & 87.65 & 80.93 & 16.51 \\
\hline Sandy soil & 76.26 & 88.47 & 82.42 & 25.23 \\
\hline Clay soil & 76.85 & 88.61 & 82.99 & 31.19 \\
\hline Pure marble & 92.29 & 96.01 & 51.03 & 57.34 \\
\hline Impure marble & 91.40 & 95.86 & 6.70 & 43.58 \\
\hline Marble-granite mix & 91.40 & 95.64 & 27.32 & 36.70 \\
\hline
\end{tabular}

The adsorption results in all adsorbents by using certain heavy metals are as follows:

1) For copper - maximum adsorption occurs by using pure marble powder as an adsorbent, while the minimum occurs by using silty soil as an adsorbent.

2) For zinc - maximum adsorption occurs by using pure marble powder as an adsorbent, whereas the minimum occurs by using silty soil as an adsorbent.

3) For manganese - maximum adsorption occurs by using clay soil as an adsorbent, while the minimum occurs by using impure marble powder silty soil as an adsorbent.

4) For chromium - maximum adsorption occurs by using pure marble powder as an adsorbent, whereas the minimum occurs by using silty soil as an adsorbent. 
Among all soils, the maximum adsorption occurs in the clayey soil with zinc. The minimum adsorption occurs in silty soil with copper.

Among all marble powders, the maximum adsorption occurs in pure marble powder with zinc. In contrast, the minimum values occur in impure marble powder with manganese.

Among all adsorbents and heavy metals, the maximum adsorption occurs in pure marble powder with zinc. Conversely, the minimum value occurs in impure marble powder with manganese.

The maximum percentage adsorption reached $96.01 \%$ which is a very high percentage indicating that the techniques are a very good method to remove the heavy metals by the mentioned adsorbents.

Different factors affect the adsorption process: the surface area and nature of the surface of the adsorbent, the nature of the adsorbate and its concentration, and the temperature of the process; the rate of the adsorption process increased along with temperature.

\section{CONCLUSIONS}

In this study, we took discarded samples of marble powder and different types of soils found in Oman and tested them for the removal of heavy metals. The samples were collected from different regions of Oman. The distilled water was used for the preparation of the heavy metal standards. The analysis revealed that the best adsorbent used is pure marble powder and the most adsorbed heavy metal is zinc. The maximum sorption reached is $96.01 \%$ and the minimum value is $6.70 \%$. The surface area plays an important role in the adsorption process; increasing the surface area also increases the adsorption rate. The surface area of marble powder is higher than soils, thus, so is its adsorption. Moreover, the nature of the adsorbent surface has a strong effect on the adsorption process. The temperature affects the adsorption rate since temperature makes the molecules and ions closer and accelerates the adsorption process. The $\mathrm{pH}$ affects the rate of adsorption to some limit.

\section{REFERENCES}

1. Akbal F., Camci S. 2011. Copper, chromium and nickel removal from metal plating waste water by electrocoagulation. Desalination, 269(1), 214-222.

2. Aman T., Kazi A.A., Sabri M.U., Bano Q. 2008. Potato peels as solid waste for the removal of heavy metal copper (II) from waste water / industrial effluent. Colloids and Surfaces B: Biointerfaces, 63(1), 116-121.

3. Carmalau C., Bulgariu L., Macoveanu M. 2009. Cobalt (II) removal from aqueous solutions by adsorption on modified peat moss. Chemical Bulletin of "Politehnica" University of Timisoara, 54(68), 13-17.

4. Gunatilake S.K. 2015. Methods of removing heavy metals from industrial waste water. Methods, I(1), 50-56.

5. Gruszecka-Kosowska A., Baran P., Wdowin M., Franus W. 2017. Waste dolomite powder as an adsorbent of $\mathrm{Cd}, \mathrm{Pb}(\mathrm{II})$, and $\mathrm{Zn}$ from aqueous solutions. Environ Earth Sci, 76(521), 1-12.

6. Inyang M., Gao B., Yao Y., Xue Y., Zimmerman A.R., Pullammanappallil P., Cao X. 2012. Removal of heavy metals from aqueous solution by biochars derived from anaerobically digested biomass. Bioresource technology, 110, 50-56.

7. Jiang K., Sun T.H., Sun L.N., Li H.B. 2006. Adsorption characteristics of copper, lead, zinc and cadmium ions by tourmaline. Journal of Environmental Sciences. 18(6), 1221-1225.

8. Kobya M., Demirbas E., Senturk E., Ince M. 2005. Adsorption of heavy metal ions from aqueous solutions by activated carbon prepared from apricot stone. Bioresourcetechnology, 96(13), 1518-1521.

9. Migahed F., Abdelrazak A., Fawzy G. 2017. Batch and continuous removal of heavy metals from industrial effluent using microbial consortia. Int. J. Environ Sci. Technol., 14, 1169-1180.

10. Nodoushan M.H.S. and Ehrampoush M.H. 2015. Study of C (II) adsorption from aqueous solution using protein granules produced from chicken feather. Environmental Health Engineering and Management Journal, 2015, 22-36.

11. Sarioglu M., Atay U.A., Cebeci Y. 2005. Removal of copper from aqueous solutions by phosphate rock. Desalination, 181(1), 303-311.

12. Yu B., Zhang, Y. Shukla, A. Shukla, S.S., Dorris K.L. 2000. The removal of heavy metal from aquous solutions by sawdust adsorption - removal of copper. Journal of Hazardous Materials, 80(1), 33-42. 